\title{
Capital Planning
}

\author{
Prakash Deo \\ University of Houston-Downtown
}

A firm's ongoing competitive edge can be attributed, in part, to its capital planning and investment process. Potential pitfalls can arise from issues created by decentralization and a narrow focus on the short-term planning horizon. In this study, we propose a comprehensive approach for the development of capital plans and attempt to simplify the maze of planning views and plans in a corporation. This process contains several action items and milestones, including setting the evaluation criteria for investments for the development of a capital plan and a standardized data request form with a detailed calendar for the entire organization to initiate the planning process each year. Finally, we develop a framework for project analysis or a business case to support a capital requirement.

Keywords: capital plan, capital budget, strategic plan, business plan, business case, planning calendar and capital request

\section{INTRODUCTION}

Capital planning is the process of budgeting funds for a firm's long-term plans. To ensure ongoing success, firms need to innovate and improve their competitive advantages, which, in turn, entails continuous investment in assets. Companies may be occupied by the attempt to satisfy shareholders' yearnings for short-term wealth maximization even if it does not lead to innovation and improved productivity and is detrimental to the long-term appreciation of shareholder wealth. The fact that a company is large, growing, and financially strong with significant competitive advantages today does not assure its success tomorrow. Most of the top 100 US. companies in 1919 have totally disappeared 100 years later. The loss of a firm's competitive edge can be attributed, in part, to failures in its capital planning and investment process. Some of these failures are due to decentralization and an excessive focus on a short-term planning horizon. Other causes include divergence between the strategic plan and the capital plan at the long-term planning stage, disconnect between the one-year business plan and the one-year capital program at the short-term planning stage, and deviations in the one-year commitment budget and the one-year capital budget at the final stage of planning. The commitment budget and the one-year capital budget are also used as templates for implementation and monthly tracking in the forthcoming year. Despite the hard work of all participants involved in the capital planning process, however, numerous issues in the process of planning, implementation, and financial controls can lead to less than acceptable results and, ultimately, disagreements and dissatisfaction among all participants.

This study seeks to 1) develop first a comprehensive approach to the development of capital plans while simplifying the maze of planning views and plans in a corporation, 2) develop a framework that will encourage academicians to conduct further research in this area, 3) encourage textbook authors to devote 
greater attention to the development of the planning process and to linkages among the strategic and financial issues, and finally, 4) develop a planning organization structure.

\section{LITERATURE REVIEW}

Several studies and textbooks discuss the effects of capital expenditures or acquisition of fixed assets on financial statements, break-even point, accounting, and financial performance measures, such as return on assets, asset turnover, and economic measures (e.g., economic value added [EVA]; see Haka, 2007; Graham and Harvey, 2001). The literature on capital investment also examines a litany of issues in capital budgeting (see Keown et al., 2020; Brealey et al., 2019; Brigham and Daves, 2015; Brigham and Houston, 2019; Ross et al., 2016; Brigham and Ehrhardt, 2019; Ehrhardt and Brigham, 2016; Gitman and Zutter, 2019. Some of the books provide an extensive discussion on capital budgeting (Shapiro, 2005; Baker and English, 2011). By and large, the literature is concerned less with the capital planning process than with project specific decisions about capital investments and their impact on a firm's financials. Van Horne (1992, p. 135) observes that because the planning process varies greatly from firm to firm, it is difficult to generalize. It may also have led to a lack of finance literature on this aspect of capital management. To that end, this study is an attempt to examine at the firm level the capital planning process, which includes several phases that span almost the entire calendar year. The level and type of capital expenditures identified in the capital programs seem to be important to investors as they communicate information about the expected growth of sales and earnings (McConnell and Muscarella, 1985). Van Horne (1992) points out that the greater the capital outlay, the greater the number of screens or approvals, varying from middle-level managers to the board of directors. This screening process allows top management to concentrate on the most critical investment proposals. Corr (1983) and Edge and Irvine (1981) discuss approaches to evaluate capital expenditure proposals and provide a summary sheet used by a firm for its internal capital expenditure request.

We will define and discuss the capital and associated expenses and then explore the various phases of planning process and the associated plans.

\section{CAPITAL EXPENDITURES AND ASSOCIATED OPERATING EXPENSES}

An expenditure that offers benefits for time periods in more than just the current accounting period is known as capital expenditure. An asset acquired with this capital is recognized as a gross fixed asset in the balance sheet. The costs associated with fixed assets are the capital costs to procure the fixed assets and the operational costs from using these fixed assets to produce goods and provide service. The evaluation process for acquisition of fixed assets will have a major influence on future operating costs, which will include the ongoing operating costs from fixed assets already in place and the additional operating costs associated with acquisition of new fixed assets. If a firm incurs expenditures to maintain a fixed asset in a running condition rather than to increase its useful life or productivity, then these outlays are treated as revenue expenditure. According to US GAAP, any disbursement that benefits the current accounting period is treated as an expense in the current accounting period. While the fixed assets are deployed in its operations, a firm continues to incur revenue expenditures known as operating costs. The major components of operational costs are depreciation, labor, and material. These operational costs are treated as fixed costs.

\section{PLANNING PHASES AND PLANNING VIEWS IN A FIRM}

This planning process and resulting planning views vary among firms depending on the size and structure of the organization. We proceed to discuss the typical three stages of planning phases and associated planning views in medium to large size firms. 


\section{Phase 1: Strategic Plan and Capital Plan}

Phase 1A: Strategic Plan

The world "strategy" implies an integrated set of actions, plans and programs that marshals and deploys resources to achieve goals and objectives that will increase the long-term well-being of the firm. Strategic planning is the organized process of developing and sustaining a practical balance between an organization's objectives, resources, and its opportunities. Strategic responsibility is the responsibility to ensure a company's future by leap-frogging competition, moving in new directions, and skillfully adapting to external forces. A strategic plan has goals related to

a) growth,

b) profitability,

c) market share,

d) consistency, and

e) management of risk.

In short, the strategic plan serves as the foundation for shareholder wealth maximization. A company's strategic plan defines the mission of a business, sets objectives, and establishes long-range targets as well as short-term goals and targets. The plan includes the current state of the company, market opportunities, strategic thrust, business direction, expected benefits, and resource requirements. Business units within a corporation generally have a specific set of products or services, a clear market focus, and a specific business strategy consistent with the corporate strategy.

Generally, the corporate headquarters coordinates with business unit counterparts to develop a standardized set of multi-year financial and strategic assumptions and requirements over a long planning period. These assumptions and requirements include consumers' product and service needs, changing spending patterns, economic forecasts, competitive and regulatory environments, state of technology, industry size, and industry growth rates. In summary, a firm's strategic plan is a clear statement of company's vision and mission, and it provides guidance, direction, and boundaries for development of the business plan, which includes specifics essential for implementation of the strategic plan. In addition, it provides boundaries for one-year plans, which are discussed later in this study. Finally, a strategic plan for a firm identifies capital expenditures as one of many key resource requirements.

\section{Phase 1B: Capital Plan}

A capital plan identifies both short-term and long-term capital resource requirements for investment projects that maintain operations, improve productivity, and ensure sustained growth. It involves planning, financing, and management of major capital outlays whose benefits lie in the future. The plan is based on a long-term investment profile and strategic objectives. The capital plan incorporates all business units' specific multiple-year, planned capital outlays and investment programs that support the objectives identified in the strategic plan. The same standard set of strategic and financial assumptions that are consistent with the development of the strategic plan are used in the development of the capital plan. The capital management department is responsible for development of the capital plan.

\section{Phase 2: Business Plan and Capital Program}

\section{Phase 2A: Business Plan}

As the long-range planning cycle winds down, the first year of the strategic plan evolves into a business plan for the following year. A business plan encompasses both marketing and operational plans. The marketing plan documents marketing tactics that guide the following year's product and service offering decisions to implement the strategic plan. In the same vein, an operational plan for annual capital expenditures includes specific programs that are designed to create capacity and support marketing tactics. These specific marketing and operational tactics and programs are designed to achieve specific financial goals. The performance measures and milestones are identified and include both financial and non-financial indicators of a firm's success in implementing its strategy. 


\section{Phase 2B: Capital Program}

Much as the first year of the strategic plan develops into a business plan for the following year, the first year of the capital plan turns into a capital program for the forthcoming year. A capital program is the integration of projects embedded in the business proposals that are essential to implementing an operational plan. It includes specific tactics that guide capital expenditure decisions and actions to implement investment decisions adopted in the operational plan. The capital program is based on requirements needed to optimize the core business and new initiatives within capital affordability targets. The capital affordability at the firm level is determined by a host of factors such as revenue and earnings growth, debt level, and capital market conditions, as well as long-term investment profile and strategic objectives. Conversely, the capital allocation to each business unit is based on its respective long-term investment profile and strategic objectives. The office of the chair of the board of directors has the authority to allocate capital resources among the business units, and as such it reviews and approves each business unit's capital program and related projects prior to inclusion in a firm's capital program, which also represents the highest funding level.

\section{Phase 3: Commitment Budget and Capital Budget}

\section{Phase 3A: Commitment Budget}

A commitment budget is a tool used for both planning and control. It is an integration and qualification of expected sales, expenses, volume, production cost, and all other operating and financial decisions. It provides a basis for monitoring and controlling performance via a monthly book close process to ensure that it conforms with the business plan. The commitment budget helps to manage the formulation of goals, coordination of its operations, and the way in which the goals are to be implemented. In other words, it paves a path to firm up the implementation plan. In summary, it helps to express the objectives in quantitative terms

\section{Phase 3B: Capital Budget}

A capital budget refers to anticipated capital purchases and capital lease bookings for the forthcoming year with due consideration to timing differences, compliance with accounting and regulatory requirements, and potential management intervention. A capital budget is a mechanism for implementing a capital program. It provides a method for controlling expenditures by monitoring capital outlays. The monthly and quarterly progress reports (i.e., comparisons of actual capital expenditures versus budgeted amount during the book close process in accordance with appropriate accounting and managerial procedures) are designed to accomplish the control objectives.

Table 1 shows the annual planning calendar and summarizes the activities, documentation requirements at various stages, and the outcomes at each stage of the planning cycle.

TABLE 1

\section{PLANNING CALENDAR}

\begin{tabular}{|c|c|c|}
\hline Timeframe & Activities & Outcome \\
\hline January & $\begin{array}{l}\text { Preliminary negotiations with business units/divisions about } \\
\text { corporate directions and objectives. }\end{array}$ & \\
\hline $\begin{array}{l}\text { February- } \\
\text { March }\end{array}$ & $\begin{array}{l}\text { Corporate headquarter communicates results of mutually } \\
\text { agreed goals and basic economic assumptions to business } \\
\text { units and divisions. }\end{array}$ & $\begin{array}{l}\text { Start of the strategic } \\
\text { and capital plan (multi- }\end{array}$ \\
\hline April & $\begin{array}{l}\text { Business units submit to the corporate headquarters their } \\
\text { strategic plan and capital management division submits } \\
\text { capital plan supported by high-level business cases. }\end{array}$ & \\
\hline June & $\begin{array}{l}\text { Analysis and presentations of the strategic plans: Company } \\
\text { level and he business unit and division levels }\end{array}$ & $\begin{array}{l}\text { Strategic and capital } \\
\text { plan presentations }\end{array}$ \\
\hline
\end{tabular}




\begin{tabular}{|c|c|c|}
\hline August & $\begin{array}{l}\text { Corporate office communicates to business units and } \\
\text { divisions updated economic assumptions. Any } \\
\text { contingencies and related plan of actions. } \\
\text { Corporate office and business units make decisions on } \\
\text { major financial activities such as dividend policy, capital } \\
\text { structure, and capital programs. }\end{array}$ & $\begin{array}{l}\text { Start of the business } \\
\text { plan and capital } \\
\text { program (one year) }\end{array}$ \\
\hline October & $\begin{array}{l}\text { Business units and divisions submit to the corporate office } \\
\text { one year preliminary operational and financial plans. The } \\
\text { capital program is supported by full business cases for } \\
\text { proposal level or economic analysis for implementation } \\
\text { level. }\end{array}$ & $\begin{array}{l}\text { Preliminary business } \\
\text { plan and capital } \\
\text { program (one year) }\end{array}$ \\
\hline $\begin{array}{l}\text { October- } \\
\text { November }\end{array}$ & $\begin{array}{l}\text { Budget negotiations between corporate office and business } \\
\text { units and divisions. }\end{array}$ & $\begin{array}{l}\text { Start of the } \\
\text { commitment budget } \\
\text { and capital budget }\end{array}$ \\
\hline \multirow[t]{2}{*}{ December } & $\begin{array}{l}\text { Business units and divisions submit one-year commitment } \\
\text { budget and capital budget and is supported by business } \\
\text { tracking plan. }\end{array}$ & $\begin{array}{l}\text { Commitment budget } \\
\text { and capital budget (one } \\
\text { year) presented to the } \\
\text { board of directors for } \\
\text { approval }\end{array}$ \\
\hline & $\begin{array}{l}\text { Board of directors approve the commitment and capital } \\
\text { budget }\end{array}$ & $\begin{array}{l}\text { The annual planning } \\
\text { process ends for the } \\
\text { year. }\end{array}$ \\
\hline
\end{tabular}

\section{THE CAPITAL PLANNING PROCESS}

The capital planning process is a three-step process that involves the development of a capital plan, the capital program, and finally the capital budget. The capital plan embedded in the overall strategic plan of a firm is reviewed and approved by an operations committee, which generally includes the vice presidents of all business units or divisions and is coordinated by the vice president of operations in a capital management division. The vice president of operations is responsible for the entire capital program in a company.

The goal of the operations committee is to assign a high-level prioritization of capital projects and provide a preliminary guidance for the development of the capital program - but without approval of specific projects. Finally, to prioritize the capital projects, this committee establishes criteria for evaluating all projects. The meeting of the operations committee occurs early in the planning cycle for inclusion of the capital plan in the overall strategic plan for the company.

The list of capital projects is developed in consultation with each business unit. Panel A of Exhibit 2 is an example of a typical data request template sent by corporate headquarters to the business units and divisions for the development of the capital plan (Phase 1) during the March-April time-period. This data request is accompanied by detailed instructions and definitions for completing the data form and a preliminary list of all capital projects. This list typically includes projects that require $\$ 5$ million to $\$ 10$ million capital expenditures for each business unit. This dollar amount depends on the size of the company. The example in Table 2 assumes the following:

1. The current year is 2022 and the strategic plan is for years 2023-2027. By the end of the year 2022, the company will develop a commitment budget and a capital budget for the year 2023

2. The discount rate is $10 \%$ based on overall risk assessment of all projects by the treasury department, although the discount rate will vary based on the risk assessment of each project and, as such, will be incorporated in a full business case.

3. The data requested for items j, I, and $m$ will be entered in the column labeled 2022 in the exhibit as each of these are cumulative figures. 
4. Analysts who supply the data are subject matter experts in their respective business units and understand the calculation of net present value.

5. During this process, the committee also reviews the status of the current year (2022) capital expenditures, and therefore, the committed capital request is only for the current year (2022) and represents the capital expenditures already incurred or committed and not yet paid.

Panel B of Table 2 includes requests for qualitative information for the same list of capital projects for the development of the capital plan. In this example, we assume that the company's main objective is to achieve a certain level of sustainable growth rate by the end of the fifth year of the plan.

TABLE 2

PROJECT DATA/INFORMATION REQUESTS FOR THE CAPITAL PLAN

\section{Panel A. General Data/Information Request Form}

\section{Capital Project Name:}

Director/Manager Sponsor:

Vice President Sponsor:

Project Description:

Data request: (see attached for definitions)

\section{a. Capital \$}

b. Committed capital

c. Revenue

d. Operating expense excluding depreciation

e. Depreciation expense

f. Operating income $f=(c-d-e)$

g. Cash taxes paid

h. Cash flow $(h=[f+e-a-g])$

i. Discounted cash flow (use $10 \%$ discount rate)

j. 5-year NPV (sum of line I, years 2023-2027)

k. Discounted capital \$ (Use 10\% discount rate)

1. 5-year total present value of capital $\$$ (sum of line k)

m. 5-year NPV per capital \$(i/l)

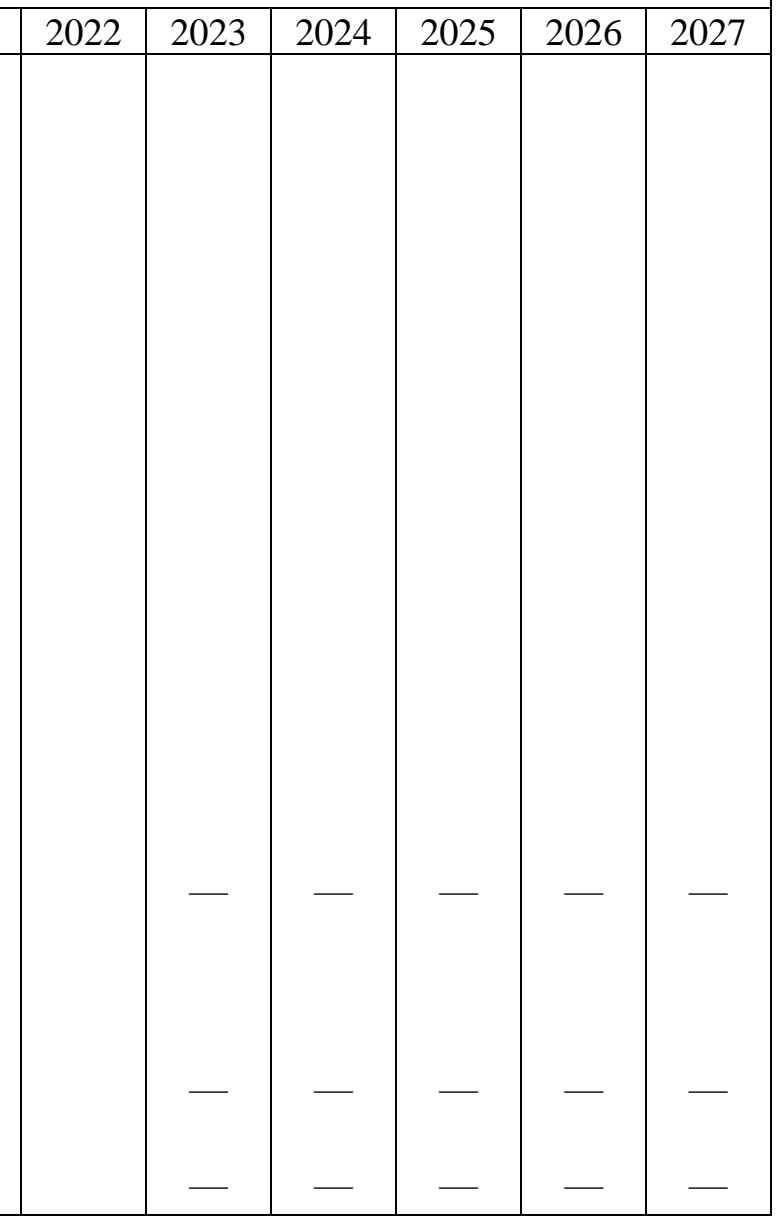


Panel B. Qualitative Data Request Form

Strategic value to company's end of the 5th year revenue growth objective:

(Evaluate this project on a scale of $0-10$ with $0=$ None and $10=$ Extremely Critical)

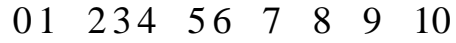

Rationale:

Other subjective considerations:

Legal requirements (e.g., taxation, regulatory, environment, etc.)?

If yes, describe:

Brand protection? $\quad$ Yes $\quad$ No

If yes, describe:

Service impacting? $\quad$ Yes $\quad$ No

If yes, describe:

The second step involves development of the capital program (phase 2) during the August-October period of the year. At this stage, the goal is to select and approve specific projects among those prioritized by the operations committee during the March-April period. Generally, this process will use the decision management model, which was utilized during the March-April period by the operations committee. Here the intent is to collect project-level information to develop a plan for the following year's (2023) capital program within the prescribed capital objectives approved by the operations committee. To that end, three years of project-level data (2023-2025) are collected and evaluated together to understand the linkages and assessment of overall impact based on financial and strategic contributions. In our illustration, the company plans to achieve its revenue growth objective by the end of the fifth year. Table 3 provides an example of the templates for data collection for each project in the program, which are once again supplemented by definitions and instructions for completing the templates. This data collection request is sent by corporate headquarters to the business units and division during the August-September period.

The data request may include an additional template for requesting qualitative data to rank the project from low, medium, or high for different features of the project or strategic initiatives that can help to achieve the five-year objective for the company. The instructions may clarify how to identify and allocate capital, revenue, and expenses for a project by year. The total net present value is calculated based on the economic life of each project. 
TABLE 3

PROJECT DATA/INFORMATION REQUESTS FOR NEXT YEAR'S (2023)

CAPITAL PROGRAM

Panel A. Project Name and Description

\begin{tabular}{|l|}
\hline Capital Project Name: \\
\hline $\begin{array}{l}\text { Director/Manager Sponsor: } \\
\text { Vice president Sponsor: }\end{array}$ \\
\hline Project Description: \\
\\
\end{tabular}

Panel B. Project Data-Expenditures and Revenue

Data request: (See attached for definitions)

(in \$ millions)

Is this project core business ___ Non-Core business ___ ?

\begin{tabular}{|l|l|l|l|}
\hline a. Capital \$ & 2023 & 2024 & 2025 \\
b. Revenue & & & \\
c. Operating expense including depreciation & & & \\
d. Cash flow net of cash income taxes & & & \\
e. Discounted cash flow (Use 10\% discount rate & & \\
f. Payback period & & & \\
g. Total NPV & & \\
\hline
\end{tabular}

Was capital approved and spent prior to 2023 on this project ? YES

NO

Panel C. Project Data-Classification of Capital by Business Drivers

\begin{tabular}{|l|l|l|l|l|l|l|}
\hline \multicolumn{2}{|c|}{ \$ Millions } & \multicolumn{3}{c|}{$\%$} \\
\cline { 2 - 7 } & 2023 & 2024 & 2025 & 2023 & 2024 & 2025 \\
\hline Maintenance & & & & & & \\
\hline Growth & & & & & & \\
\hline Reliability & & & & & & \\
\hline Cost reductions & & & & & & \\
\hline Infrastructure & & & & & & \\
\hline International & & & & & & \\
\hline Strategic initiatives & & & & & & \\
\hline
\end{tabular}

Phase 2 ends up with a plan for attainment of the capital program objectives and approval of related capital projects.

In Phase 3, during the October-November period, the bottom-up data collection of approved projects is conducted by the capital management team from headquarters via a data request (not shown in any exhibits). This view serves a financial tracking vehicle for the following year's (2023) performance in the financial systems. It includes a detailed information by category (growth, maintenance, etc.) on new construction expenditures, additions to depreciable plant, retirements, and other items on both a quarterly and an annual basis. 


\section{BUSINESS CASES}

\section{Business-Level Business Case for Inclusion in a Capital Plan}

A business-level (versus project-level) business case is a high-level analysis of business proposal and corresponding projects that provides sufficient information for prioritization in supporting specific capital investments for inclusion in the capital plan (Phase 1). Projects included in the business-level business cases are rank ordered on their relative net present value to capital ratio as well as strategic factors. Other financial factors, including earnings, net present value, and discounted payback period, may also be considered. The planning cycle ends with the board of directors' approval of the capital budget, usually in December, for its implementation in the following year and to track the next year's actual performance. Business case data are collected in Phase 2 to support the resource allocation process. At that time, the business-level business case information may be sparse in underlying project details and an analysis of product and service plans may be conducted in aggregate. The analysis of plans at an aggregate level is treated as a high-level business Alternatively, to alleviate these deficiencies, a business or operational plan may be viewed as an aggregation of high-level product and service plans.

A product or service plan may include several project plans. A product plan is supported by two types of business cases: (1) a high-level or macro business case, which combines several product business cases, and justifies at an aggregate level the total shared capital among a group of products as well as capital associated with a specific product, and (2) an individual product business case that justifies product-specific capital associated with unique strategy or marketing program.

\section{Full or Detailed Business Case}

A full or detailed business case is a complete analysis and documentation of a business proposal including results of possible alternatives. As the operational plan activities progress during the planning year and details become explicit, a more rigorous business case is developed. Alternatively, the high-level business case may be firmed up. This iteration helps meet the requirement to gain capital funding first, in the capital program (Phase 2) and then in the capital budget and is followed by the final authorization of the business proposal and corresponding projects as delineated in a firm's schedule of authorization. It also helps to manage implementation activities.

The purpose, significant assumptions, resource requirements, investment drivers, and key financial and operational measures that support a business decision are presented in the full business case. The operational measures refer to items such as the implementation schedule, milestones, and a tracking plan, while the financial measures include such items as earnings, net present value of cash flow, and the discounted pay-back period.

\section{Economic Decision Analysis}

A capital project may involve one or more discrete implantation decisions. These decisions or activities are commonly known as project authorization requests. An economic decision analysis is performed at the implementation stage prior to ordering equipment. This step is useful to determine the optimal solution and may be performed to supplement already approved business case. The economic analysis invariably entails a comparison of present values of cash flows of all available options. For instance, at this stage of approval for the recommended alternative, further economic analysis may be performed to select a supplier who meets the specific requirements among all external suppliers, who may or may not have been identified in the full business case.

\section{Business Case Guidelines}

Firms create a standardized set of guidelines for the development of business cases for presentation to the management for making capital investment decisions related to specific business and operational proposals. These guidelines complement a firm's expenditure authorization policy included in its schedule of authorizations. 


\section{DOCUMENTATION REQUIREMENTS}

Analysis of a business proposal is conducted prior to any investment, expenditure of funds, or retirements of assets. The analysis is documented in either in a business letter or in a business case. The required document varies depending on the total cost involved in the proposal. For instance, if the cost is less than $\$ 10,000$ to implement, the analysis may be documented in a business letter; otherwise, the analysis is documented in a business case. A business case is developed for all types and categories of projects, including projects needed for growth, maintenance, cost reduction, and so on. (See Appendix A.)

\section{Business Letter}

A business letter is a document, generally no more than four pages long, that provides business purpose, benefits, resource requirements, cost justification, and quantification of benefits for the proposal. It includes the total cost of the proposal and its impact on the firm. Finally, the findings from the analysis are presented in a summary format.

\section{Business Case}

A business case is based on a general methodology designed to identify proposals that will result in effective utilization of a firm's resources. The guidelines to follow apply to both high-level and full business cases. The submission requirements vary by business case category.

\section{Business Case Requirements}

These requirements identify the information that should be included in a business case. The business case should include the following sections: executive summary, proposal description, business partner concurrence, alternatives, financial analysis, risk analysis, recommendations, and a tracking plan. A business case may comprise one or more projects, and where more than one project is required, the package must include specifications and associated dollar value of all projects required to implement the project.

Executive Summary. The executive summary is an overview that briefly presents all relevant proposal information necessary to understand the request. It includes the objectives and the basic needs for the expenditure, recommended alternatives, implementation dates, and general benefit information. Additionally, it includes financial information, such as revenue growth, cost savings, resource requirements, operating income, net present value of cash flows, and discounted payback period.

Proposal Description. In this element, describe the proposal and briefly outline the business needs for the service. Identify the corporate drivers as defined in the company's investment planning guidelines approved by the operations committee. Address strategic issues and impacts related to sales or the provision of the service and circumstances surrounding the proposal's implementation including special dates or events. Describe the present mode of operations and discuss the need for a change in the mode of operation. Include in this section global assumptions that were made, including but not limited to market share and competition.

Business Partner's Concurrence. In some cases, multiple business units and support divisions may be responsible for implementation of a proposal. Obtain concurrence from each business partner when the project involves more than one business segment. Discuss all business partners' commitments related to documentation where concurrence is not provided. Finally, include the reasons for the delay along with the anticipated time frame when the commitment is expected.

Alternatives. Briefly list all realistic alternatives considered for the proposal including, if relevant, the present mode of operation. Summarize all information relevant to each alternative, including assumptions, technology requirements, strategic benefits, and financial results detailed in the financial analysis section. In addition, include risk analysis for each alternative. Indicate any realistic alternatives that were not considered. Provide the reasons for not considering them. Include all detailed analysis and provide specific assumptions supporting various alternatives considered in the business case in the appendices.

Financial Analysis. Provide the proposal-specific assumptions, pricing and volume, and cost assumptions. Include the business unit's and support division's budget impact, net present values, operating 
income, discounted payback period, net present value index on capital, and internal rate of return. The results for each alternative evaluated should be presented in the business case in the appendices.

Proposal-Specific Assumptions. Summarize the proposal-specific assumptions used for each alternative. Use the firm's business planning assumptions for all other factors.

Budget Impact. Ensure the expenses and capital required for the implementation of the proposal are in each business unit's and support division's budget. When the funding is not included in the budget, identify any re-prioritization or funding process agreement reached with a business unit and or a division.

Net Present Value (NPV). NPV is the primary economic measure of a proposal's worth. Summarize the results of cumulative effect of the proposal's after-tax incremental cash flows on the business unit, support division, and the company. Provide NPV of cash flows over the life of the proposal for each alternative. Identify the NPV for each alternative and, where applicable, compare them with the present mode of operations to determine the savings. Highlight the least cost and the selected alternatives.

Operating Income. Operating income is the operating revenue less operating variable and fixed costs. It excludes non-operating income, interest or any other financing charges, and taxes. It is a short-term financial measure of operating profit. Summarize the consolidated results of the impact on both the business unit and the entire company. Provide the earnings impact of the least cost and the selected alternatives.

Discounted Payback Period (DPP). The discounted payback period is the time needed for the discounted cash inflow in the proposal to recover the initial cash investment. Provide the time in years required for the cumulative present value of the net incremental cash flows to equal or exceed zero and remain non-negative for the remainder of the study.

Net Present Value Index on Capital (NPVIc). NPVIc is an indicator of the efficiency with which capital funds are used, is defined as the cumulative net present value of cash inflow divided by the present value of the capital expenditures. In a capital rationing environment, NPVIc may be used to rank-order projects for prioritization.

Internal Rate of Return (IRR). IRR is defined as the discount at which the NPV of cash flow streams equals zero. It represents the highest discount at which a proposal is economically beneficial to the company.

Sensitivity Analysis. Sensitivity analysis relative to the key value drivers is an essential part of the financial analysis. This includes but is not limited to changes in assumptions, forecasts, and funding availability. The sensitivity analysis also helps determine the key risks to the proposal by the changes in the financial results. The analysis should minimally include the factors changed, the degree of change incorporated, and the resulting financial indicators.

Provide financing alternative results. Lease-versus-buy analyses are generally done at the time of the acquisition. For proposals that are close to the inception of the proposal, however, the analysis may be completed concurrent with the development of the business case and an economic decision analysis.

Risk Analysis. The impact of the proposal's risk is an integral part of assessing the economics of a proposed investment. Incorporate risk in the evaluation of the selected choice and alternative resource investment possibilities directly by adjusting for the risk factors or by applying the appropriate cost of capital. Risks include such factors as market condition that may change radically and, as a result, projected cash flows that may not materialize.

Economic Decision Analysis. Economic decision analysis is designed to address all issues related to discrete business decisions and specific implementation activities. An approved capital project may involve one or more discrete implementation decisions. Economic decision analysis is performed at the implementation stage prior to ordering equipment. This is conducted to determine the optimal solution and is performed to supplement an already approved business case. This invariably entails comparison of present values of cash flows of all available options, such as selection of a supplier who meets the specific requirements among all external suppliers, who may or may not have been identified in the full business case.

Recommendation. Identify the recommended alternative that is being requested for authorization. Include the key financial results. Identify any other financial indicators that are relevant to the selection of 
the best alternative and are used for strategic alignment. Complete a "Recommendation summary," such as shown in Appendix B.

Proposal Tracking Plan. Proposal tracking is the process of monitoring the financial and operational results and critical assumptions of a proposal and comparing those results with those forecasts. State the proposed objective and significant milestones. Provide a plan to track all measures included in meeting the proposal objective and the proposal evaluation methodology that will measure operational and financial performance. Identify the associates and organization responsible for business case tracking and time periods when tracking reports will be generated. Minimum requirements for tracking business cases should be quarterly.

Appendices. This section should include exhibits detailing analysis of each alternative. It should include a detailed description of the capital, expenses, and incremental cash flow per year over the life of the project. Sensitivity analysis, lease-versus-buy analysis, and all other relative supporting information, such as detailed market forecasts, must be provided in this section. The business partners' commitment letter(s) would also be included here.

\section{Schedule of Authorization}

Approval of business letters and business cases must adhere to the firm's schedule of authorization. The schedule identifies who can authorize expenditures. It provides guidance as to the expenditure authorization levels. For projects that cut across multiple units, a linkage to the primary business case must be established and all business partners must agree to implement the proposal.

\section{CONCLUSION}

Capital planning is the process of budgeting funds for the future of a firm's long-term plans. To ensure ongoing success, firms need to innovate and improve their competitive advantages, which entails incessant investment in assets. Companies may be occupied in their pursuit to satisfy their shareholders' yearnings for short-term wealth maximization even if it does not lead to innovation and improved productivity and is detrimental to long-term appreciation of shareholder wealth. The loss of a firm's competitive edge can be attributed in part, to failures in its capital planning and investment process. Potential issues can be created by decentralization, too much focus on a short-term planning horizon, and divergences from the strategic plan and the capital plan at the long-term planning stage or the annual commitment budget and capital budget at the final short-term planning stage. To purge any inconsistencies, firms need to establish a planning process to achieve concurrent and consistent multiple planning views at various stages. This process may contain several action items and milestones, including setting the evaluation criteria for investments for the development of a capital plan and a standardized data request with a detailed calendar for the entire organization with the calendar initiating the planning process each year. Finally, the capital planning process may require a project analysis or a business case to support a capital requirement.

In this study, we have proposed a comprehensive and a phased approach to capital planning and reconciled the maze of planning views and plans in a corporation. We then developed a framework that will motivate academicians to conduct further research in this area. With the backdrop of this planning process and framework, we encourage textbook authors to devote greater attention to the planning process and to linkages among the strategic and financial issues at each phase of planning. Finally, we recommend firms to develop an organization structure to meet the needs at each phase of planning in a coordinated fashion to ensure a sense of achievement among all participants in the planning process. 


\section{REFERENCES}

Baker, K.H., \& English, P. (2011). Capital Budgeting Valuation. Hoboken, NJ: John Wiley and Sons, Inc. Brealey, R., Myers, S., \& Marcus, A. (2019). Fundamentals of Corporate Finance (10th edition). New York: McGraw-Hill Education.

Brigham, E., \& Daves, P.R. (2022). Intermediate Financial Management (14th edition). Masson, OH: Cengage Learning.

Brigham, E., \& Ehrhardt, M. (2019). Fundamentals of Financial Management (15th edition). Masson, $\mathrm{OH}$ : Cengage Learning.

Brigham, E., \& Houston, J.F. (2019). Intermediate Financial Management (14th edition). Masson, OH: Cengage Learning.

Corr, A.V. (1983). The Capital Expenditure Decision. New York: National Association of Accountants.

Edge, C.G., \& Bruce, V.I. (1981). A Practical Approach to the Appraisal of Capital Expenditures (2nd edition). Hamilton, ON, Canada: The Society of Management Accountants.

Ehrhardt, M.C., \& Brigham, E.F. (2016). Financial Management: Theory and Practice (15th edition). Masson, $\mathrm{OH}$ : South-Western Cengage Learning.

Gitman, L.J., \& Zutter, C.J. (2019). Principles of Managerial Finance (14th Edition). Pearson Series in Finance, New York, New York.

Graham, J.R., \& Harvey, C.R. (2001). The theory and practice of corporate finance evidence from the field. Journal of Financial Economics, 60, 187-243.

Haka, S.F. (2007). A Review of the Literature on Capital Budgeting and Investment Appraisal: The Past, Present, and Future Musings. In C.C. Chapman, A. Hopwood, \& M. Shields (Eds.), Handbook of Management Accounting Research, (Volume 2, pp. 697-728). Oxford: Elsevier.

Keown, A.J., Martin, J.D., \& Petty, J.W. (2020). Foundations of Finance. New York: Pearson.

McConnell, J.J., \& Muscarella, C.J. (1985, September). Corporate Capital Expenditures Decisions and the Market Value of the Firm. Journal of Financial Economics, 14, 399-422.

Ross, S., Westerfield, R., \& Jordan, B. (2016). Fundamentals of Corporate Finance (11th edition). New York: McGraw-Hill Education.

Shapiro, A.C. (2004). Capital Budgeting and Investment Analysis. Upper Saddle River, NJ: Pearson Prentice Hall.

Van Horne, J.C. (1992). Financial Management and Policy. Englewood Cliffs, NJ: Prentice Hall.

\section{APPENDIX A: BUSINESS CASE REQUIREMENTS SUMMARY}

Documentation requirements for a high-level business case, a full business case and a business letter are summarized in the following table.

\begin{tabular}{lccc} 
& \multicolumn{2}{c}{ Business Case } & \\
\cline { 2 - 3 } & High Level & Full & Business Letter \\
\hline Executive summary & Yes & Yes & No \\
Business proposal & Yes & Yes & Yes \\
Business partner concurrence & Yes & Yes & Yes \\
& & & \\
Alternatives & & & No \\
Strategic alternatives & Yes & Yes & Yes \\
Proposal alternatives & Yes & Yes & \\
& & & \\
Financial analysis & & & Yes \\
Cost-Benefit (rev., exp., and op. inc.) & Yes & Yes & No \\
Performance indicators (NPV, NPVIc, DPP) & Yes & Yes & No \\
Details & No & Yes & \\
\hline
\end{tabular}


Risk analysis

Strategic (brand protection, etc.)

Proposal risk analysis

Yes Yes No

Yes Yes No

Economic decision analysis

Recommendations

No $\quad$ Yes $\quad$ No

Tracking plan

Yes Yes

Yes

Appendices

No

Yes

Yes

Approval per schedule of authorization

Yes

Yes

Yes

No Yes

Yes

\section{APPENDIX B: RECOMMENDATION SUMMARY}

Business unit:

Business case name:

Business purpose:

Capital request:

Five-year NPV:

Discounted pay-back period:

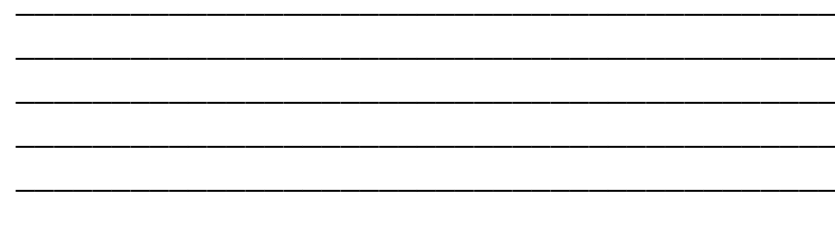

$\$$
Study period NPV:
Total NPV Internal rate of return:

\begin{tabular}{|l|l|l|l|l|l|}
\hline & 2023 & 2024 & 2025 & 2026 & 2027 \\
\hline Incremental & & & & & \\
\hline Revenue & & & & & \\
\hline Expense & & & & & \\
\hline Operating Income & & & & & \\
\hline Capital & & & & & \\
\hline Cumulative discounted cash flow & & & & & \\
\hline Business case assumptions & \\
- & \\
-
\end{tabular}

